\author{
Тарасова О.В. \\ кандидат економічних наук, доцент \\ кафедра обліку та аудиту \\ Одеська національна академія харчових технологій \\ вул. Канатна, 112, м. Одеса, Україна, 65039 \\ E-mail: tarasovaelenaonaft@gmail.com
}

\title{
ФІНАНСОВА ПОЛІТИКА І БЮДЖЕТНА БЕЗПЕКА УКРАЇНИ
}

У статті досліджуються проблеми забезпечення бюджетної безпеки України, яка відіграє надзвичайно важливу роль у розвитку суспільства. Розглянуто зміст фінансової політики як частини економічної політики держави. Визначені методологічні принципи, на базі яких має здійснюватися фрінансова політика: орієнтованість на кінцеву мету; макроекономічна збалансованість усіх галузей економіки; відповідність інтересам всіх членів суспільства; використання економічних законів; врахування внутрішніх і зовнішніх фракторів впливу. Обґрунтовано роль фрінансової політики у забезпеченні стабільного економічного зростання. Визначені основні загрози бюджетній безпеці України: високий рівень державного боргу; значний дефіцит державного бюджету; підвищення частки видатків державного бюджету на фінансування потреб оборони та безпеки; інфляційно-девальваційні коливання. Сформульовані завдання, вирішення яких дозволить оптимізувати фінансову політику.

Ключові слова: фрінансова політика; фінансова система; державне регулювання; бюджетна безпека; економічне зростання.

This work is licensed under a Creative Commons Attribution 4.0 International License http://creativecommons.org/licenses/by/4.0/

Постановка проблеми та її зв'язок з важливими науковими та практичними завданнями. На сучасному етапі розвитку економіки в умовах недосконалості ринкового механізму об'єктивною необхідністю виступає регулювання соціальноекономічних процесів з боку держави. Підтвердженням зростання ролі державного регулювання економіки виступає той факт, що сукупні обсяги централізованих грошових фондів розвинутих країн в середньому складають близько $50 \%$ ВВП. В ході історичного процесу держава стала здійснювати функції регулятора економічних відносин. При цьому найважливішим інструментом державних органів управління $\epsilon$ фінансова політика, через яку реалізується регулююча функція фінансової системи держави.

Фінансову політику можна охарактеризувати як сукупність розподільних i перерозподільних заходів, які здійснює держава через фінансову систему. Фінансова політика $\epsilon$ частиною економічної політики держави. Її головним завданням є забезпечення реалізації державних програм відповідними фінансовими ресурсами. Фінансова політика проявляється у фінансовому законодавстві; в системі форм і методів мобілізації і використання фінансових ресурсів, найважливішими 3 яких $\epsilon$ податки; в перерозподілі фінансових ресурсів між окремими верствами населення, галузями економіки, територіями; в структурі доходної і видаткової частин бюджетів.

Фінансова політика відіграє велику роль в функціонуванні кожної держави. Вона може здійснювати сприятливий вплив на розвиток продуктивних сил, покращення добробуту населення, підвищення обороноздатності країни, що набуває все більшої актуальності в умовах військових дій на Сході України.

Аналіз останніх публікацій 3 проблеми. Дослідження теоретичних та практичних аспектів фінансової політики відображені в працях вітчизняних і зарубіжних вчених В. Базилевича, I. Балабанова, С. Льовочкіна, В. Опаріна, І. Плікуса, К. Савченко, В. Федосова [1-5] та ін. Водночас, недостатньо досліджені проблеми забезпечення бюджетної безпеки держави потребують особливої уваги.

Формулювання цілей дослідження. Метою статті $є$ дослідження впливу фінансової політики на бюджетну безпеку України в сучасних умовах.

Виклад основних результатів та їх обгрунтування. Фінансова політика $\epsilon$ складовою фінансової системи, яка в свою чергу є частиною економічної системи держави. Таким чином, фінансова політика є частиною економічної політики держави. Фінансову політику можна охарактеризувати як діяльність органів державної влади з управління фінансовою системою, метою якої $є$ вплив на процес розширеного відтворення та задоволення потреб суспільства.

Основні методологічні принципи, на базі яких має здійснюватися фінансова політика, наступні: орієнтованість на кінцеву мету; макроекономічна збалансованість усіх галузей економіки; відповідність інтересам всіх членів суспільства; використання економічних законів; врахування внутрішніх і зов- 
нішніх факторів впливу.

На сучасному етапі розвитку вітчизняної економіки необхідним є створення такої системи, яка б сприяла виникненню стимулів до забезпечення відповідального управління фінансовими ресурсами держави i проведенню фінансової політики, спрямованої на реалізацію стійкого економічного зростання. Для впровадження відповідної фінансової політики важливим питанням $\epsilon$ визначення оптимальної частки перерозподілу ВВП через зведений бюджет держави. Воно зводиться до вибору одного $з$ альтернативних рішень: підвищення ролі держави у регулюванні економіки або проведення економічної лібералізації.

Військовий конфлікт на Сході України привів до загострення проблем і незбалансованості у різних ланках бюджетної системи. Особливе занепокоєння викликає стан бюджетної безпеки держави. «Бюджетна безпека держави - це стан забезпечення платоспроможності та фінансової стійкості державних фінансів, що надає можливість органам державної влади максимально ефективно виконувати покладені на них функції» [6].

На сьогоднішній день основними загрозами бюджетній безпеці України, на нашу думку, слід вважати:

1. Високий рівень державного боргу. За даними Міністерства фінансів державний та гарантований державою борг України станом на 31 січня 2017 року становив 1.931,02 млрд. грн., або 71,21 млрд. дол. США. У тому числі: зовнішній борг (державний та гарантований державою) склав 1.241,33 млрд. грн. (64,28\% від загальної суми державного та гарантованого державою боргу), або 45,77 млрд. дол. США; внутрішній борг (державний та гарантований державою) - 689,69 млрд. грн. (35,72\%), або 25,43 млрд. дол. США.

При иьому державний борг Украӥни становив $1.651,69$ млрд. грн. (85,53\% від загальної суми державного та гарантованого державою боргу), або 60,91 млрд. дол. США. Зовнішній державний борг становив 981,05 млрд. грн. (50,80\% від загальної суми державного та гарантованого державою боргу), або 36,18 млрд. дол. США. Внутрішній державний борг складав 670,64 млрд. грн. (34,73\% від загальної суми державного та гарантованого державою боргу), або 24,73 млрд. дол. США.

Гарантований державою борг України становив 279,33 млрд. грн. (14,47\%), або 10,30 млрд. дол. США. В тому числі: гарантований зовнішній борг 260,28 млрд. грн. (13,48\%), або 9,60 млрд. дол. США; внутрішній гарантований борг - 19,05 млрд. грн. (0,99\%), або 0,70 млрд. дол. США.

Протягом січня 2017 року у гривневому еквіваленті сума державного та гарантованого державою боргу України збільшилася на 1,26 млрд. грн., при цьому державний та гарантований державою борг збільшився на 0,23 млрд. дол. США у доларовому еквіваленті. Головною причиною цих змін стало фінансування державного бюджету за рахунок державних запозичень, а також капіталізація двох банків: ПАТ "Державний експортно-імпортний банк України" (відповідно до Постанови КМУ від 01.02.2017 № 54) та ПАТ "Державний ощадний банк України" (відповідно до Постанови КМУ від 01.02.2017 № 55) [7].

Щорічне зростання видатків на обслуговування державного боргу створює ефект «витіснення» для фінансування інших важливих для економічного зростання напрямів видатків.

2. Значний дефіиит державного бюджету. У 2016 році дефіцит державного бюджету України становив 70,3 млрд. грн., що складає 2,9 \% ВВП. В 2018 році граничний обсяг дефіциту державного бюджету передбачається у розмірі 80,6 млрд. грн., що складає 2,4\% ВВП [8].

Основними джерелами покриття дефіциту бюджету в Україні служать надходження від приватизації, а також випуск облігацій внутрішньої державної позики. При цьому, невиконані плани з приватизації в останні роки приводять до необхідності додаткової емісії державних цінних паперів, що в свою чергу збільшує державний борг.

3. Підвищення частки видатків державного бюджету на фінансування потреб оборони та безпе$\kappa u$. Відповідно до Закону «Про державний бюджет України на 2018 рік» [8] видатки для Міністерства оборони України передбачено у сумі 83324500,0 тис. грн., що на 192877100,0 тис. грн. більше, ніж у 2017 року і на 27686571,6 тис. грн. більше, ніж було в 2016 році. При цьому головною проблемою, на нашу думку, залишаються питання обліку та підвищення ефективності використання бюджетних коштів у цій cфepi.

4. Інфляичійно-девальвачійні коливання. За даними НБУ, у січні 2017 року відносно січня 2016 року грошова маса зросла на 71 млрд. грн., або 7,1\% 3995 до 1066 млрд. грн. Таке зростання значною мірою відбулось саме за рахунок готівки в обігу, що збільшилась за рік на 23 млрд. грн., або на 8,4 \% 3272 до 295 млрд. грн. [9]. Таким чином, інфляція в Україні носить монетарний характер.

Основні індикатори стану бюджетної безпеки України відображають той факт, що має місце недостатня стійкість державних фінансів. Це приводить до формування ланцюга системних внутрішніх загроз бюджетній безпеці України. Слід відмітити і низьку спроможність протистояти зовнішнім ризикам, таким як: зниження купівельної спроможності населення, згортання обсягів кредитування економіки, погіршення інвестиційного клімату в країні, негативні прогнози щодо кон'юнктури на світових ринках сировини.

На сучасному етапі розвитку українського суспільства, в умовах все ще високого рівня корупції, великого значення набуває вирішення проблеми підвищення ефективності та прозорості державних (публічних) фінансів. Міжнародний Валютний Фонд (МВФ) дає наступне визначення поняттю «фіскальна прозорість» - повнота, надійність, ясність, актуальність і своєчасність публічної звітності про минулий, поточний та майбутній стан публічних 
фінансів [10].

На тлі реформування сфери державних фінансів в Україні все більшого значення набуває ефективність управління інформаційними ресурсами. Прозорість державних фінансів є необхідною умовою контролю за ефективністю їх розподілу і стає визначальним фактором для успішного реформування національної економіки. В останні роки реалізовано низку успішних ініціатив в цьому напрямку. Високі стандарти якості розкриття державних даних повинні стати важливим інструментом у боротьбі з такими недоліками, як неефективність, корупція та популізм в сфері державного управління та сприяти бюджетній і фінансовій безпеці України.

Висновки та перспективи подальших досліджень. Проведене дослідження дає змогу запропонувати наступні шляхи удосконалення фінансової політики в Україні:

- для підвищення ефективності управління державним боргом необхідно вжити заходів щодо недопущення формування «прихованого» дефіциту державного бюджету та непрогнозованого зростання державного боргу, а також розробити стратегію та сформувати дієвий механізм управління державним боргом;

- в зв'язку з тим, що в умовах нагромадження державного боргу та дефіциту державного бюджету відбувається зростання соціальних зобов'язань держави, суттєвого вдосконалення потребує система соціальної підтримки населення. $\mathrm{У}$ структурі соціальних видатків найбільшу частку складають видатки на соціальний захист та соціальне забезпечення, освіту та охорону здоров'я. Хоча номінальні показники видатків щорічно зростають, головною проблемою залишається низька якість надання державних соціальних послуг. Для “ї розв'язання необхідно здійснити перехід від механізму бюджетного утримання до забезпечення розвитку соціальної сфери;

- важливо здійснити поступове зниження облікової ставки, забезпечення додатного рівня про- центних ставок НБУ відносно прогнозованої базової інфляції, що сприятиме зниженню девальваційних та інфляційних очікувань $\mathrm{i}$ досягненню показників інфляції у 2018 році в розмірі $6 \pm 2$ в.п.

- доцільне стимулювання своєчасного повернення та збільшення надходження валютних коштів підприємств-експортерів в Україну (через механізм автоматичного відшкодування ПДВ, реалізацію домовленостей щодо підвищення розміру квот $Є \mathrm{C}$ на український експорт та усунення штучно створених транзитних перешкод на шляху українських товарів до країн СНД через територію РФ, а також шляхом поетапного зниження норм обов'язкового продажу їх виручки);

- необхідне прийняття довгоочікуваного закону «Про валютне регулювання в Україні», в якому має бути узагальнено чинну нормативно-правову базу 3 валютного регулювання, що дозволить учасникам ринку формувати свою валютну стратегію, враховуючи чіткі довгострокові правила;

- запорукою успішного проведення економічних реформ в Україні $\epsilon$ забезпечення прозорості державних фінансів i підвищення ефективності управління ними.

За результатами проведених досліджень, основні проблеми у фіскальній сфері у майбутньому будуть зосереджені у напрямку управління державним боргом, у діяльності позабюджетних фондів та в управлінні дефіцитом державного бюджету, що обумовлює необхідність проведення бюджетної консолідації та підвищення ефективності управління бюджетними коштами. Зменшення бюджетних ризиків в першу чергу залежатиме від формування дієвих бюджетних важелів, які дадуть змогу оперативно і ефективно реагувати на внутрішні і зовнішні виклики. В зв'язку з цим, подальші дослідження будуть спрямовані на проблеми мінімізації бюджетних ризиків.

\section{Література}

1. Базилевич В. Д. Державні фінанси: [навч. посіб.] / В. Д. Базилевич, Л. О. Баластрик ; за заг. ред. В. Д. Базилевича. - К.: Ari, 2004. - 363 c.

2. Балабанов А. И. Финансы: [учеб. пособие] / А. И. Балабанов, И. Т. Балабанов. - СПб. : Питер, 2002. $188 \mathrm{c}$.

3. Опарін В. М Фінанси (загальна теорія): [навч. посібник] / В. М. Опарін. - [2-ге вид., доп. і перероб.]. - К.: КНЕУ, 2001. -240 c.

4. Савченко К. В. Можливості використання фінансової політики держави для стабілізації національної економіки // Збірник наукових праць Національного університету державної податкової служби України. 2013. - №2. - С. 44-55.

5. Федосов В. Фінансова реструктуризація в Україні: проблеми і напрями: [монографія] / В. Федосов, В. Опарін, С. Льовочкін. - К. : КНЕУ, 2002. - 387 с.

6. Методичні рекомендації щодо розрахунку рівня економічної безпеки України. Затверджено Наказом Міністерства економічного розвитку і торгівлі України від 29.10.2013 № 1277. - [Електронний ресурс]. - Режим доступу: $\quad$ http://cct.com.ua/2013/29.10.2013 1277.htm

7. Офіційний сайт Міністерства фінансів України. - [Електронний ресурс]. - Режим доступу: https://www.minfin.gov.ua/news/view/statystychni-materialy-shchodo-derzhavnoho-ta-harantovanoho-derzhavoiuborhu-ukrainy_2016?category=borg\&subcategory 
8. Закон України «Про державний бюджет України на 2018 рік» № 2246-19 : за станом на 07.12.2017. [Електронний ресурс]. - Режим доступу: http://zakon3.rada.gov.ua/laws/show/2246-19

9. Додаток до макроекономічного та монетарного звіту за лютий 2017 р. - [Електронний ресурс]. - Peжим доступу: https://bank.gov.ua/control/uk/publish/article?art id=43297262\&cat id=58037

10. Офіційний сайт Міжнародного валютного фонду. - [Електронний ресурс]. - Режим доступу: http://www.imf.org/external/np/fad/trans/

Стаття надійшла 1.02.2018

Стаття прийнята до друку 15.02.2018

Доступно в мережі Internet 31.03.2018

Тарасова E.B.

кандидат экономических наук, доцент

кафрдра учета и аудита

Одесская национальная академия пищевых технологий

ул. Канатная, 112, г. Одесса, Украина, 65039

E-mail: tarasovaelenaonaft@gmail.com

\title{
ФИНАНСОВАЯ ПОЛИТИКА И БЮДЖЕТНАЯ БЕЗОПАСНОСТЬ УКРАИНЫ
}

В статье исследуются проблемы обеспечения бюджетной безопасности Украины, которая играет чрезвычайно важную роль в развитии общества. Рассматривается содержание фринансовой политики, как части экономической политики государства. Сформулированы методологические принципы, на базе которых должна осуществляться финансовая политика: ориентированность на конечную цель; макроэкономическая сбалансированность всех отраслей экономики; соответствие интересам всех членов общества; использование экономических законов; учет внутренних и внешних фракторов влияния.

Обоснована роль финансовой политики в обеспечении стабильного экономического роста. Определены основные угрозы бюджетной безопасности Украины: высокий уровень государственного долга; значительный дефицит государственного бюджета; рост доли расходов бюджета на фринансирование сектора обороны и безопасности; инфляционно-девальвационные колебания.

Сделан вывод о том, что ежегодный рост расходов на обслуживание государственного долга создает эффрект «вытеснения» для финансирования других важных для экономического роста направлений расходов.

Источниками финансирования дефицита бюджета являются поступления от приватизации, а также государственные займы. При этом невыполнение планов по приватизации приводит к необходимости дополнительного выпуска государственных ценных бумаг, что в свою очередь увеличивает государственный долг.

Проанализирована динамика расходов государственного бюджета на оборону и безопасность. При этом отмечается, что важной проблемой остаются вопросы учета и эффективности использования бюджетных средств. Сформулированы задачи, решение которых позволит оптимизировать фринансовую политику.

Ключевые слова: финансовая политика; финансовая система; государственное регулирование; бюджетная безопасность; экономический рост.

\author{
Tarasova O. \\ $\mathrm{PhD}$, Associate Professor \\ Department of Accounting and Auditing \\ Odessa National Academy of Food Technologies \\ st. Kanatna, 112, Odessa, Ukraine, 65039 \\ E-mail: tarasovaelenaonaft@gmail.com
}

\section{FINANCIAL POLICY AND BUDGET SECURITY OF UKRAINE}

The article examines the problems of ensuring Ukraine's budget security, which plays an extremely important role in the development of society. The content of financial policy as part of the state's economic policy is considered. The methodological principles are formulated on the basis of which the financial policy 
should be implemented: focus on the ultimate goal; macroeconomic balance of all sectors of the economy; conformity to the interests of all members of society; use of economic laws; accounting for internal and external factors of influence.

The role of financial policy in ensuring stable economic growth is substantiated. The main threats to Ukraine's budget security are identified: a high level of public debt; high level of deficit of the state budget; an increase in the share of budget expenditures for financing the defense and security sector; inflationdevaluation fluctuations.

It is concluded that the annual increase in expenditures on servicing the public debt creates the effect of "crowding out" to finance other areas of expenditure that are important for economic growth.

Sources of financing the budget deficit are revenues from privatization, as well as government loans. At the same time, non-fulfillment of privatization plans leads to the need for an additional issue of government securities, which in turn increases public debt.

The dynamics of state budget expenditures on defense and security is analyzed. At the same time, it is noted that issues of accounting and efficiency of using budget funds remain an important problem. The tasks are formulated, the solution of which will allow optimizing the financial policy.

Keywords: financial policy; financial system; state regulation; budget security; the economic growth.

\section{References}

1. Bazylevych, V. D., \& Balastryk, L. O. (2004). Derzhavni finansy (V. D. Bazylevych, Ed.). K.: Ari.

2. Balabanov, A. I., \& Balabanov, I. T. (2002). Finansyi. Piter: SPb.

3. Oparin, V. M. (2001). Finansy (2nd ed.). K.: KNEU.

4. Savchenko, K. V. (2013). Mozhlyvosti vykorystannia finansovoi polityky derzhavy dlia stabilizatsii natsionalnoi ekonomiky. Zbirnyk naukovykh prats Natsionalnoho universytetu derzhavnoi podatkovoi sluzhby Ukrainy, (2), 44-55.

5. Fedosov, V., Oparin, V., \& Lovochkin, S. (2002). Finansova restrukturyzatsiia v Ukraini: Problemy i napriamy. K.: KNEU.

6. Metodychni rekomendatsii shchodo rozrakhunku rivnia ekonomichnoi bezpeky Ukrainy. Zatverdzheno Nakazom Ministerstva ekonomichnoho rozvytku i torhivli Ukrainy vid 29.10.2013 № 1277. (2013). Retrieved from http://cct.com.ua/2013/29.10.2013 1277.htm

7. Ofitsiinyi sait Ministerstva finansiv Ukrainy. Retrieved from https://www.minfin.gov.ua/news/view/statystychni-materialy-shchodo-derzhavnoho-ta-harantovanoho-derzhavoiuborhu-ukrainy_2016?category=borg\&subcategory

8. Zakon Ukrainy «Pro derzhavnyi biudzhet Ukrainy na 2018 rik» № 2246-19 : Za stanom na 07.12.2017.

(2017). Retrieved from http://zakon3.rada.gov.ua/laws/show/2246-19

9. Dodatok do makroekonomichnoho ta monetarnoho zvitu za liutyi 2017 r. (2017). Retrieved from https://bank.gov.ua/control/uk/publish/article?art_id=43297262\&cat_id=58037

10. Ofitsiinyi sait Mizhnarodnoho valiutnoho fondu. Retrieved from http://www.imf.org/external/np/fad/trans/

Received 1 February 2018

Approved 15 February 2018

Available in Internet 31.03.2018 